\title{
Pengetahuan Dan Minat Vaksinasi Covid-19 Masyarakat di Kota Gorontalo dan Kabupaten Bone Bolango
}

\author{
Edwina Rugaiah Monayo \\ Fakultas Kedokteran Universitas Negeri Gorontalo \\ Email: ewi_doc@ung.ac.id
}

\begin{abstract}
Abstrak
Pandemi COVID-19 yang melanda dunia saat ini, telah menyebabkan morbiditas dan mortalitas yang tinggi di seluruh dunia. Program vaksinasi yang diberikan pemerintah Indonesia bertujuan menanggulangi pandemi Covid-19. Hasil beberapa survey menunjukkan masih banyak masyarakat Indonesia yang menolak divaksin Covid-19. Tujuan penelitian ini adalah untuk untuk menganalisis tingkat pengetahuan dan minat masyarakat Kota Gorontalo Dan Kabupaten Bone Bolango terhadap vaksinasi Covid-19.

Desain penelitian merupakan penelitian deskriptif. Populasi adalah masyarakat di Kota Gorontalo dan Kabupaten Bone Bolango yang bukan berlatar belakang pendidikan kesehatan. Pengambilan sampel secara purposive sampling, dengan kriteria sampel usia 18-80 tahun. Penelitian dilakukan pada bulan JuniSeptember 2021. Hasil penelitian adalah sebesar yaitu 70 responden (50\%) memiliki tingkat pengetahuan cukup tentang vaksinasi Covid-19, 38 responden (27\%) memiliki tingkat pengetahuan baik, dan 32 responden $(23 \%)$ memiliki tingkat pengetahuan kurang tentang vaksinasi Covid-19. Untuk minat responden, yang berminat untuk dilakukan vaksinasi Covid-19 yaitu 78 responden (56\%), dan yang tidak berminat untuk mengikuti vaksinasi Covid-19 juga masih cukup tinggi, yaitu 62 responden (44\%).

Kesimpulan sebagian besar masyarakat Gorontalo memiliki tingkat pengetahuan cukup tentang vaksinasi Covid-19 dan berminat untuk dilakukan vaksinasi Covid-19.
\end{abstract}

Kata Kunci : Vaksinasi, Covid-19, Pengetahuan, Minat

\section{Covid-19 Vaccination Knowledge And Interests Of The Gorontalo City And Bone Bolango Regency Community}

Abstract

The COVID-19 pandemic that is sweeping the world today, has caused high morbidity and mortality worldwide. The vaccination program provided by the Indonesian government aims to stop the Covid-19 pandemic. The results of several surveys show that there are still many Indonesians who refuse to be vaccinated against Covid-19. The purpose of this study was to analyze the level of knowledge and interest of the Gorontalo City and Bone Bolango Regency community towards the Covid-19 vaccination.

A descriptive research design is used in this study. People in Gorontalo City and Bone Bolango Regency who do not have a background in health education comprise the population. Purposive sampling has been used, with a sample age range of 18 to 80 years. From June to September 2021, the study was carried out. The results of the study were 70 respondents $(50 \%)$ had a sufficient level of knowledge about Covid-19 vaccination, 38 respondents (27\%) had a good level of knowledge, and 32 respondents $(23 \%)$ had a low level of knowledge about Covid-19 vaccination. Judging from the interest, respondents who are interested in getting the Covid-19 vaccination are 78 respondents (56\%), and those who are not interested in participating in the Covid-19 vaccination are also still quite high, namely 62 respondents (44\%).

The conclusion is that most of the people of Gorontalo have a sufficient level of knowledge about the Covid-19 vaccination and are interested in getting a Covid-19 vaccination.

Keywords: Vaccination, Covid-19, Knowledge , interests 
PENDAHULUAN

Coronavirus mulai menyebar di Wuhan, Tiongkok pada Desember 2019. Organisasi Kesehatan Dunia (WHO) secara resmi memberikan nama penyakit ini dengan Coronavirus Disease 2019 (COVID-19) pada 11 Februari 2020 (Sun, Lu, Xu, Sun, \& Pan, 2020). Penyebaran COVID-19 kemudian terus berlangsung dengan cepat hingga banyak negara terjangkit COVID-19, sampai pada 30 Januari 2020, WHO mendeklarasikan wabah COVID-19 di Cina sebagai kedaruratan kesehatan masyarakat yang meresahkan dunia (Public Health Emergency of International Concern, PHEIC) ini menandakan COVID-19 sebagai ancaman global dunia (Makmun and Hazhiyah, 2020).

Data statistik Johns Hopkins University Medicine bulan Februari 2021 mencatat Indonesia turut menyumbang 1,11 persen kasus positif Covid-19 di dunia dan menempatkan Indonesia di posisi ke-19 penyumbang kasus positif Covid-19. Berdasarkan laman resmi Johns Hopkins University Medicine, tercatat 1.191.990 kasus konfirmasi Covid-19 di Tanah Air. Dengan persentase tersebut, Indonesia saat ini menempati urutan ke-19 kasus sebaran Covid-19 dari 192 negara yang sudah terpapar virus tersebut. Sementara itu, untuk angka kematian di Tanah Air mencapai 32.381 jiwa atau setara 1,38 persen dari angka kematian secara global yakni 2.357.270 jiwa.

Meskipun pembatasan jarak fisik, karantina, dan isolasi, efektif dalam menekan jumlah orang yang terinfeksi selama pandemi dalam jangka pendek, namun tidak adanya kekebalan dalam populasi membuat seseorang rentan terhadap gelombang infeksi SARS-CoV2 lebih lanjut (Flaxman et al., 2020).

Vaksinasi adalah cara yang sederhana, aman, dan efektif untuk melindungi seseorang dari penyakit berbahaya. Vaksinasi menggunakan pertahanan alami dari tubuh untuk membangun ketahanan terhadap infeksi tertentu dan membuat sistem kekebalan tubuh menjadi lebih kuat. Saat divaksinasi, seseorang tidak hanya melindungi dirinya sendiri, tetapi juga orang-orang di sekitarnya. Terutama bagi seseorang dengan penyakit kronis yang tidak terkontrol dan tidak disarankan untuk mendapatkan vaksin tertentu, sehingga mereka bergantung pada orangorang yang mendapatkan vaksinasi untuk 
membantu mengurangi penyebaran

penyakit (Flaxman et al., 2020; Larson et

al., 2015). Itulah yang membuat vaksinasi menjadi hal yang paling tepat untuk saat ini dalam menanggulangi penyebaran COVID-19. Semakin banyak orang yang divaksin, maka semakin sedikit orang yang tetap rentan dan semakin kecil pula kemungkinan penularan patogen dari orang ke orang. Inilah yang disebut sebagai Herd Immunity (WHO, 2021).

Herd Immunity terjadi ketika persentase penduduk yang tinggi yang divaksinasi, sehingga penyakit menular sulit menyebar, karena tidak banyak orang yang dapat tertular. Tetapi kekebalan kelompok hanya bekerja jika sudah banyak orang yang telah melakukan vaksinasi (Fontanet \& Cauchemez, 2020)

Sejak wabah dimulai, peneliti di seluruh dunia telah mencoba mengembangkan vaksin COVID-19 diantaranya CoronaVac (Sinovac Life Science) adalah inactivated vaccine dalam melawan COVID-19 dan telah menunjukkan imunogenisitas yang baik pada mencit, tikus, dan primata nonmanusia dengan antibodi penetralisir yang diinduksi oleh vaksin terhadap
SARS-CoV-2 dan dapat menetralkan sepuluh strain representatif dari SARSCoV-2 (Sanche et al., 2020). Vaksin ini telah dikembangkan uji klinis pada manusia (Zhang et al., 2021). Pelaksanaan vaksinasi Covid-19 di Indonesia dilaksanakan secara bertahap setelah vaksin mendapatkan izin dari BPOM berupa Emergency Use of Authorization (EUA). Untuk mendukung Program pemerintah agar seluruh masyarakat Indonesia ikut mensukseskan keberhasilan vaksinasi Covid 19. (Kemenkes RI, 2021)

Hingga saat ini masih ada saja masyarakat Indonesia yang menolak divaksinasi dengan berbagai alasan dalam mencegah virus Covid-19 (Wulanningrum, 2021), diantaranya takut akan efek samping vaksin, takut sakit menjadi lebih parah, kehalalan dari vaksin tersebut dan alasan lain yang mungkin penyebabnya adalah kurangnya pengetahuan masyarakat tentang vaksinasi Covid 19, sehingga mengurangi minat masyarakat melakukan vaksinasi Covid 19. Untuk itu peneliti melakukan penelitian tentang tingkat pengetahuan dan minat masyarakat Gorontalo terhadap vaksinasi Covid 19. 


\section{METODE PENELITIAN}

Desain penelitian adalah penelitian observasional yang dianalisis secara dekskriptif. Lokasi penelitian di Kota Gorontalo (wilayah kerja Puskesmas Kota Tengah) dan Kabupaten Bone Bolango (wilayah kerja Puskesmas Suwawa) Provinsi Gorontalo. Waktu penelitian pada bulan Juni hingga Juli 2021. Populasi adalah masyarakat di wilayah kerja Puskesmas Kota Tengah Kota Gorontalo dan wilayah kerja Puskesmas Suwawa Kabupaten Bone Bolango Provinsi Gorontalo. Adapun tehnik pengambilan sampel, purposive sampling dengan kriteria sampel adalah bersedia menjadi responden, usia 18-80 tahun dan bukan tenaga kesehatan atau memiliki latar belakang pendidikan Kesehatan.

Analisis data yang digunakan dalam penelitian ini adalah analisis univariat. Analisis univariat berfungsi untuk meringkas kumpulan data hasil pengukuran sedemikian rupa sehingga kumpulan data yang diperoleh tersebut berubah menjadi informasi yang berguna, dan pengolahan datanya hanya satu variabel saja. Variabel yang diteliti
Pengetahuan dan minat masyarakat

Gorontalo terhadap vaksinasi Covid 19.

\section{HASIL PENELITIAN}

I. Karakteristik Responden

a. Distribusi Responden Berdasarkan Jenis Kelamin Responden

Berdasarkan hasil penelitian yang telah dilakukan, diperoleh distribusi responden berdasarkan jenis kelamin pada tabel sebagai berikut :

Tabel 1. Distribusi responden berdasarkan

\begin{tabular}{|c|c|c|c|}
\hline No. & $\begin{array}{c}\text { Jenis } \\
\text { Kelamin }\end{array}$ & $\mathbf{n}$ & $\%$ \\
\hline 1. & Laki-Laki & 49 & 35 \\
\hline 2. & Perempuan & 91 & 65 \\
\hline \multicolumn{2}{|r|}{ Jumlah } & 140 & 100 \\
\hline
\end{tabular}

diketahui bahwa dari 140 responden yang diteliti didapatkan jenis kelamin perempuan yang terbanyak sebagai responden, yaitu 91 orang (65\%).

b. Distribusi Responden Berdasarkan Umur Responden

Berdasarkan hasil penelitian yang telah dilakukan, diperoleh distribusi responden berdasarkan umur pada tabel sebagai berikut : 
Tabel 2. Distribusi

Responden

Berdasarkan Umur

\begin{tabular}{|c|c|c|c|}
\hline No & Umur & n & \% \\
\hline 1 & $17-25$ Tahun & 41 & 29 \\
2 & $26-35$ Tahun & 24 & 17 \\
3 & 36- 45 Tahun & 27 & 19 \\
4 & $46-55$ Tahun & 25 & 18 \\
5 & $56-65$ Tahun & 15 & 11 \\
6 & $>$ 65 Tahun & 8 & 6 \\
\hline & TOTAL & $\mathbf{1 4 0}$ & $\mathbf{1 0 0}$ \\
\hline
\end{tabular}

Berdasarkan umur responden,

diketahui bahwa dari 140 responden, kelompok umur terbanyak adalah rentang 17-25 tahun yaitu sebanyak 41 responden (29\%) dan termasuk dlam kelompok remaja akhir.

c. Distribusi Responden Berdasarkan Tingkat Pendidikan Responden Berdasarkan hasil penelitian yang telah dilakukan, diperoleh distribusi responden berdasarkan tingkat Pendidikan responden pada tabel sebagai berikut :

Tabel 3. Distribusi reponden berdasarkan tingkat Pendidikan

\begin{tabular}{|c|c|c|c|}
\hline No & $\begin{array}{c}\text { Tingkat } \\
\text { Pendidikan }\end{array}$ & $\mathbf{n}$ & \% \\
\hline 1 & $\begin{array}{c}\text { Tidak Sekolah } \\
\text { Pendidikan } \\
\text { Dasar } \\
\text { (SD/SMP) }\end{array}$ & 2 & 1 \\
3 & $\begin{array}{c}\text { Pendidikan } \\
\text { Menengah } \\
\text { (SMU) } \\
\text { Pendidikan } \\
\text { Tinggi }\end{array}$ & 67 & 48 \\
\hline \multicolumn{2}{|c|}{ Jumlah } & 140 & 100 \\
\hline
\end{tabular}

Berdasarkan Tingkat Pendidikan Responden diketahui bahwa dari 140 responden mewakili distribusi tingkat Pendidikan responden tinggi dan rendah.

d. Distribusi Responden Berdasarkan Pekerjaan Responden

Berdasarkan hasil penelitian yang telah dilakukan, diperoleh distribusi responden berdasarkan pekerjaan pada tabel sebagai berikut :

Tabel 4. Distribusi Responden Berdasarkan Pekerjaan

\begin{tabular}{|c|l|c|c|}
\hline No & \multicolumn{1}{|c|}{ Pekerjaan } & n & \% \\
\hline 1 & PNS/TNI/POLRI/BUMN & 6 & 4 \\
2 & Pegawai Swasta & 9 & 6 \\
3 & Wiraswasta & 5 & 4 \\
4 & Pengemudi Bentor & 4 & 3 \\
5 & Ibu Rumah Tangga & & \\
& (IRT) & 62 & 44 \\
6 & Buruh Bangunan & 4 & 3 \\
7 & Petani & 4 & 3 \\
8 & Tidak Bekerja & 16 & 11 \\
9 & Lain-Lain & 30 & 21 \\
\hline \multicolumn{2}{|r|}{ TOTAL } & $\mathbf{1 4 0}$ & $\mathbf{1 0 0}$ \\
\hline
\end{tabular}

Berdasarkan pekerjaan responden diketahui bahwa dari 140 responden yang terbanyak adalah responden yang merupakan ibu rumah tangga, sebanyak 62 responden ( $44 \%)$.

e. Distribusi Responden Berdasarkan Status Perkawinan Responden

Berdasarkan hasil penelitian yang telah dilakukan, diperoleh distribusi responden berdasarkan status 
perkawinan responden pada tabel sebagai

berikut :

Tabel 5. Distribusi responden berdasarkan status perkawinan

\begin{tabular}{|c|c|c|c|c|}
\hline No. & $\begin{array}{c}\text { Status } \\
\text { Perkawinan }\end{array}$ & n & \% \\
\hline 1. & & Menikah & 97 & 69 \\
2. & & $\begin{array}{c}\text { Belum } \\
\text { Menikah }\end{array}$ & 43 & 31 \\
\hline \multicolumn{2}{|l}{} & Jumlah & $\mathbf{1 4 0}$ & $\mathbf{1 0 0}$ \\
\hline
\end{tabular}

Berdasarkan status perkawinan responden bahwa dari 140 responden, Sebagian responden sudah menikah, yaitu 97 responden (69\%).

f. Distribusi Responden Berdasarkan Status Vaksinasi Covid 19

Berdasarkan hasil penelitian yang telah dilakukan, diperoleh distribusi responden berdasarkan status vaksinasi Covid 19 pada tabel sebagai berikut :

Tabel 6.Distribusi responden berdasarkan Status vaksinasi Covid 19

\begin{tabular}{|c|c|c|c|}
\hline No. & $\begin{array}{c}\text { Status } \\
\text { vaksinasi } \\
\text { Covid } 19\end{array}$ & $\mathbf{n}$ & $\%$ \\
\hline 1. & $\begin{array}{c}\text { Sudah Pernah } \\
\text { vaksin }\end{array}$ & 49 & 35 \\
\hline 2. & $\begin{array}{c}\text { Belum pernah } \\
\text { vaksin }\end{array}$ & 91 & 65 \\
\hline \multicolumn{2}{|r|}{ Jumlah } & 140 & 100 \\
\hline
\end{tabular}

Berdasarkan Status vaksinasi

Covid 19 diketahui bahwa dari 140 responden yang belum pernah divaksin Covid 19 ketika kuesioner ini dibagikan, adalah 91 responden (65\%).
2.1. Distribusi Responden

Berdasarkan Tingkat

Pengetahuan Masyarakat

Gorontalo Terhadap Vaksinasi

Covid 19

Berdasarkan hasil penelitian yang telah dilakukan, diperoleh distribusi responden berdasarkan tingkat pengetahuan responden pada tabel sebagai berikut :

Tabel 7. Distribusi responden berdasarkan Tingkat Pengetahuan Masyarakat Gorontalo terhadap Vaksinasi Covid-19

\begin{tabular}{|c|c|c|c|}
\hline No. & Pengetahuan & n & \% \\
\hline 1. & Baik & 38 & 27 \\
2. & Cukup & 70 & 50 \\
3. & Kurang & 32 & 23 \\
\hline \multicolumn{2}{|c|}{ Jumlah } & $\mathbf{1 4 0}$ & $\mathbf{1 0 0}$ \\
\hline
\end{tabular}

Berdasarkan tingkat pengetahuan masyarakat tentang vaksinasi Covid-19, diketahui bahwa dari 140 responden yang diteliti didapatkan pengetahuan responden terbanyak yaitu kategori cukup sebanyak 70 responden (50\%).

2.2.Distribusi Responden Berdasarkan Minat Masyarakat Gorontalo Terhadap Vaksinasi Covid 19

Berdasarkan hasil penelitian yang telah dilakukan, diperoleh distribusi responden berdasarkan minat

II. Analisis Univariat 
responden terhadap vaksinasi Covid-

19 pada tabel sebagai berikut :

Tabel 8. Distribusi Responden Berdasarkan Minat Masyarakat Gorontalo terhadap Vaksinasi Covid-19

\begin{tabular}{|c|c|c|c|}
\hline No. & Minat & n & \% \\
\hline 1. & Ya & 78 & 56 \\
2. & Tidak & 62 & 44 \\
\hline \multicolumn{2}{|c|}{ Jumlah } & $\mathbf{1 4 0}$ & $\mathbf{1 0 0}$ \\
\hline
\end{tabular}

berdasarkan minat masyarakat

Gorontalo terhadap vaksinasi Covid-19,

diketahui bahwa dari 140 responden yang diteliti didapatkan sebagian besar responden memiliki minat untuk melakukan vaksinasi Covid sebanyak 78 responden $(56 \%)$.

\section{Pembahasan}

I. Tingkat Pengetahuan Masyarakat Gorontalo tentang vaksinasi Covid-19

Berdasarkan hasil penelitian pada tabel 7. bahwa sebagian besar pengetahuan responden di wilayah kerja Puskesmas Suwawa Kabupaten Bone Bolango dan di wilayah kerja Puskesmas Kota Tengah Kota Gorontalo memiliki pengetahuan cukup sejumlah 70 responden (50\%), 38 responden (27\%) memiliki tingkat pengetahuan baik dan 32 responden (23\%) memiliki tingkat pengetahuan kurang tentang vaksinasi covid 19.
Dari hasil penelitian didapatkan bahwa jumlah responden dengan tingkat pengetahuan cukup lebih banyak dibandingkan responden dengan pengetahuan baik. Tingkat pengetahuan yang cukup bisa disebabkan oleh kurangnya informasi yang didapatkan oleh responden tentang pentingnya vaksinasi Covid-19 atau banyaknya berita "hoaks" yang beredar dimasyarakat yang dapat menimbulkan kesalahpahaman informasi di masyararakat.

Ada beberapa faktor yang bisa menyebabkan berita bohong menjadi merajalela. Faktor-faktor seperti mencari sensasi, humor, profit oriented, ataupun hanya ikut-ikutan pihak tertentu, baik dengan sengaja menimbulkan keresahan atau ada keinginan untuk mengadu domba. Namun dari faktor-faktor tersebut, berita bohong yang merebak dengan memanfaatkan situasi tertentu seperti saat pandemi ini tak jarang karena ada maksud dan kepentingan dalam rangka menyudutkan suatu pihak dan menimbulkan keresahan. Latar belakang pendidikan yang berbeda-beda, lingkungan yang bervariasi, dan penerimaan pesan yang beraneka ragam tentu menjadi peluang dalam penyebaran 
berita bohong terkait vaksin COVID-19

(Priastuty et al., 2020).

Pengetahuan adalah hasil dari tahu, dan terjadi setelah orang melakukan penginderaan terhadap suatu objek tertentu. Sebagian besar penginderaan manusia diperoleh melalui mata dan telinga, yaitu melalui proses melihat dan mendengar. Selain itu melalui pengalaman dan proses belajar dalam pendidikan formal maupun non formal (Notoatmodjo, 2010).

Faktor yang mempengaruhi pengetahuan masyarakat tentang vaksinasi covid 19 meliputi tingkat pendidikan, Berdasarkan data hasil penelitian pada tabel 2.1. bahwa ada sekitar 58 responden (41\%) yang berlatar belakang pendidikan dasar dan menengah, memiliki pengetahuan yang cukup tentang vaksinasi covid 19. Salah satu faktor yang dapat mempengaruhi pengetahuan seseorang adalah tingkat pendidikan. Selain itu Budiman dan Riyanto (2013), juga mengatakan bahwa pendidikan formal seseorang sangat besar pengaruhnya terhadap pengetahuan. Akan tetapi ada pula responden yang berpendidikan dasar, tetapi memiliki tingkat pengetahuan yang baik tentang pentingnya vaksinasi Covid-
19. Hal ini bisa disebabkan karena saat ini informasi tentang pentingnya vaksinasi Covid 19 bisa didapatkan dengan mudah melalui media sosial, disamping itu penyuluhan-penyuluhan yang terus digerakkan oleh pihak Puskesmas, Dinas Kesehatan di Provinsi Gorontalo, juga turut membantu untuk bisa mempercepat pelaksanaan vaksin pada masyarakat Gorontalo.

Faktor lain yang mempengaruhi tingkat pengetahuan adalah pengalaman. Seseorang yang memiliki informasi lebih banyak akan memiliki pengetahuan yang lebih luas pula. Salah satu sumber informasi yang berperan penting bagi pengetahuan adalah media massa. Informasi-informasi yang telah disampaikan melalui media massa yang menjelaskan beberapa reaksi umum yang terjadi setelah vaksinasi Covid-19 meliputi nyeri atau kemerahan di sekitar tempat suntikan, gatal, demam ringan, kelelahan, mengantuk, sakit kepala, nyeri otot merupakan reaksi umum dan hanya berlangsung kurang dari seminggu serta bukan merupakan penghalang untuk dilaksanakan vaksinasi covid-19. Telah dijelaskan bahwa setiap vaksin Covid-19 telah melalui proses pengujian yang ketat untuk memastikan keamanannya. 
Sebelum didistribusikan, proses

pengujian tersebut dimaksudkan agar semua vaksin Covid-19 dapat mengurangi risiko sakit akibat virus (Kemenkes RI, 2021).

\section{Minat Masyarakat Gorontalo terhadap vaksinasi Covid-19}

Berdasarkan hasil penelitian pada tabel 9, bahwa sebagian besar responden yang diteliti di wilayah kerja Puskesmas Suwawa Kabupaten Bone Bolango dan di wilayah kerja Puskesmas Kota Tengah Kota Gorontalo berminat untuk dilakukan vaksinasi yaitu 78 responden $(56 \%)$, sementara untuk angka responden yang tidak berminat untuk divaksin masih cukup tinggi, yaitu 62 responden $(44 \%)$.

Pendorong utama kepercayaan publik terhadap vaksin diidentifikasi sebagai kepercayaan pada pentingnya keamanan vaksin, keefektifan vaksin, dan juga kompatibilitas vaksinasi dengan keyakinan agama (Larson et al., 2015). Masih tingginya angka responden yang tidak berminat untuk divaksinasi, bisa didorong oleh tingkat kepercayaan masyarakat terhadap vaksin itu sendiri.

Persepsi masyarakat terhadap merupakan faktor penting, ada banyak responden yang menganggap mendalami spiritualitas adalah cara menjaga kesehatan dan menghadapi suatu penyakit. Faktor kontekstual umum lain seperti agama, persepsi terhadap perusahaan farmasi, dan kondisi sosial, budaya, dan ekonomi juga memengaruhi penerimaan vaksin. Beberapa responden berpendapat bahwa anjuran memakai masker, mencuci tangan, dan menerapkan pembatasan sosial (3M) sudah cukup. Responden yang giat mengikuti anjuran $3 \mathrm{M}$ tersebut merasa sudah merasakan manfaatnya dan mempertanyakan rasio risiko terhadap manfaat penggunaan vaksin (Kemenkes RI,2020).

Minat sebagai kecenderungan untuk melakukan respon dengan cara tertentu disekitarnya, sehingga apa yang telah dilihat seseorang tersebut tentu akan membangkitkan minat seseorang sejauh apa yang telah dilihatnya dan mempunyai hubungan dengan kepentingannya sendiri. Menurut Slameto (2015), minat adalah suatu rasa lebih suka dan rasa ketertarikan pada suatu hal atau aktivitas, tanpa ada yang menyuruh. Minat pada dasarnya adalah kesehatan dan pencegahan penyakit juga 
penerimaan akan suatu hubungan antara

diri sendiri dengan sesuatu di luar diri.

Di Indonesia, pada awal pelaksanaan vaksinasi, kelompok yang menjadi sasaran program vaksinasi pemerintah adalah: petugas kesehatan, TNI/Polri dan aparat pelayanan publik lainnya; tokoh masyarakat, pejabat pemerintah pusat dan daerah, guru dan beberapa kelompok penerima Jaminan Kesehatan Nasional (BPJS) (Ophinni et al., 2020). Pemerintah pun semakin memperluas cakupan vaksinasi pada lansia dan masyarakat umum.

Dalam penelitian ini, terlihat bahwa masih 63 responden (44\%) yang tidak berminat untuk divaksinasi dengan berbagai alasan dari setiap responden. Sementara yang berminat untuk divaksinasi memiliki alasan sebagian karena keinginan sendiri dan adapula karena diwajibkan oleh tempat kerja/atasan/pemerintah. Semua alasan tersebut terlepas dari tujuan untuk kesehatan masyarakat itu sendiri, dimana pemerintah mencanangkan program vaksinasi Covid-19 untuk membentuk Herd imunity dalam masyarakat, khususnya pada masyarakat Gorontalo, sehingga bisa mencegah penyebaran virus Covid-19 di Provinsi Gorontalo.
Simpulan

Dari hasil penelitian dapat disimpulkan tingkat pengetahuan responden tentang vaksinasi Covid 19 yaitu dari 140 responden, sebagian besar memiliki tingkat pengetahuan cukup tentang vaksinasi Covid-19, yaitu 70 responden $(50 \%)$, kemudian tingkat pengetahuan baik 38 responden (27\%) dan terakhir tingkat pengetahuan kurang 32 responden ( $23 \%$ ). Sementara untuk minat responden dalam melaksanakan vaksinasi Covid 19 yaitu sebagian besar berminat untuk dilakukan vaksinasi Covid-19 yaitu 78 responden (56\%), dan masyarakat Gorontalo yang tidak berminat untuk mengikuti vaksinasi Covid-19 juga masih cukup tinggi, yaitu 62 responden $(44 \%)$.

\section{DAFTAR PUSTAKA}

Budiman dan Riyanto A (2013). Kapita Selekta Kuisoner. Jakarta: Salemba Medika.

Flaxman, S., Mishra, S., Gandy, A., Unwin, H. J. T., Mellan, T. A., Coupland, H., . . . Bhatt, S. (2020). Estimating the effects of nonpharmaceutical interventions on COVID-19 in Europe. Nature, 584(7820), 257-261. doi:10.1038/s41586-020-2405-7 
Fontanet, A., \& Cauchemez, S. (2020). COVID-19 herd immunity: where are we? Nature Reviews Immunology, 20(10), 583-584.

Johns Hopkins University and Medicine (2021). Covid-19 Dashboard by the Center for System Science and Engineering (CSSE). Baltimore:Johns Hopkins University and Medicine

Kementerian Kesehatan Republik Indonesia (2021). Frequently Asked Question : Seputar Pelaksanaan Vaksinasi COVID-19.

Kementerian Kesehatan Republik Indonesia (2021). Vaksinasi COVID-19 Nasional.

Larson, H. J., Jarrett, C., Schulz, W. S., Chaudhuri, M., Zhou, Y., Dube, E., . . . Wilson, R. (2015). Measuring vaccine hesitancy: The development of a survey tool. Vaccine, 33(34), 4165-4175. doi:10.1016/j.vaccine.2015.04.037

Makmun, A. and Hazhiyah, S. F. (2020) 'Tinjauan Terkait Pengembangan Vaksin Covid 19', Molucca Medica, 13, pp. 52-59. doi: 10.30598/molmed.2020.v13.i2.52

Notoatmodjo, S (2012). Metodologi Penelitian Kesehatan. Jakarta: Rineka Cipta

Ophinni, Y., Hasibuan, A. S., Widhani, A., Maria, S., Koesnoe, S., Yunihastuti, E., . . . Djauzi, S. (2020). COVID-19 Vaccines: Current Status and Implication for Use in Indonesia. Acta Med Indones, 52(4), 388-412.

Sanche, S., Lin, Y. T., Xu, C., RomeroSeverson, E., Hengartner, N., \& Ke, R. (2020). High Contagiousness and
Rapid Spread of Severe Acute Respiratory Syndrome Coronavirus 2. Emerg Infect Dis, 26(7), 14701477. doi:10.3201/eid2607.200282

Slameto (2015). Belajar dan Faktorfaktor yang mempengaruhinya. Jakarta; Rineka Cipta

Sun, P., Lu, X., Xu, C., Sun, W., \& Pan, B. (2020). Understanding of COVID-19 based on current evidence. J Med Virol, 92(6), 548551. doi:10.1002/jmv.25722

WHO (2020). Clinical management of severe acute respiratory infection (SARI) when COVID-19 disease is suspected. A systematic review of asymptomatic infections. https://www.who.int/publicationsdetail/clinicalmanagement-ofsevere-acute-respiratory- infectionwhennovel-coronavirus-(ncov)infection-is-suspected.

WHO. Whats herd immunity?official Covid 19 updates. 31 Dec. 2020. http://www/who.int/herd/immunity

Wulanningrum, H. (2021). Evaluasi Diseminasi Informasi Vaksinasi Covid-19 Melalui Media Sosial Kementerian Komunikasi dan Informatika. Dinamika dan Strategi Humas Pemerintah di Indonesia Pranata Humas Indonesia 2021, 72.

Zhang, Y., Zeng, G., Pan, H., Li, C., Hu, Y., Chu, K., . . . Zhu, F. (2021). Safety, tolerability, and immunogenicity of an inactivated SARS-CoV-2 vaccine in healthy adults aged 18-59 years: a randomised, double-blind, placebocontrolled, phase 1/2 clinical trial. Lancet Infect Dis, 21(2), 181-192. 

doi:10.1016/s1473-3099(20)308434

Priastuty, C. W. et al (2020) . Hoaks tentang Vaksin Covid-19 di Tengah Media Sosial. Prosiding Seminar Nasional Unimus, 3, pp. 391-399. 